\title{
Kriteria Green Infrastructure dalam Penentuan Luas Stasiun Kereta Api
}

\author{
NADIA ULFAH, SOFYAN TRIANA \\ Jurusan Teknik Sipil, Institut Teknologi Nasional, Bandung \\ Email: ulfahnadia@yahoo.com
}

\begin{abstract}
ABSTRAK
Pembangunan infrastruktur adalah salah satu penyebab kerusakan lingkungan saat ini. Salah satu infrastruktur yang mendukung moda transportasi kereta api adalah bangunan stasiun. Agar membangun suatu stasiun yang tidak merusak lingkungan dan memberikan ruang gerak yang nyaman kepada pengguna maka dilakukan analisis mengenai luas kebutuhan lahan menurut peraturan yang berlaku sesuai dengan salah satu kriteria bangunan hijau yaitu harus memenuhi Koefisien Dasar Bangunan (KDB) dan kebutuhan Ruang Terbuka Hijau (RTH). Data sekunder dibutuhkan dalam perhitungan luas berdasarkan ruang gerak manusia dan standar stasiun. Hasil perhitungan diperoleh luas stasiun sebesar 2.685,5 $\mathrm{m}^{2}$ yang merupakan KDB 60\% sedangkan untuk luas RTH 40\% sebesar 1.790,3 $\mathrm{m}^{2}$ sehingga diperoleh luas lahan stasiun sebesar $4.475,8 \mathrm{~m}^{2}$. Pada peraturan yang berlaku mengenai bangunan stasiun hanya membahas KDB atau luas terbangun dan tidak membahas mengenai kebutuhan RTH maka dapat diusulkan perhitungan baru untuk merancang stasiun ramah lingkungan yang membahas luas KDB dan $R T H$ sehingga didapat luas tanah keseluruhan.
\end{abstract}

Kata kunci: green infrastructure, stasiun, luas bangunan, ruang gerak manusia, Koefisien Dasar Bangunan (KDB), Ruang Terbuka Hijau (RTH).

\begin{abstract}
Infrastructure development is one of the causes of current enviromental damage. One of the infastructure supporting the train transportation capital is station building. Build a station will not be damaging the environment and giving comfortable space if it has been done analysis about wide of land environment according to the prevailling regulations in accordance with the one of the criteria of green building that fulfills Coefficient of Bulding Base (KDB) and Green Open Space (RTH). The secondary data is needed in wide calculation based on space for human movement and station standard. The calculation results obtained area of the station is 2.685,5 $\mathrm{m}^{2}$ that is KDB 60\% while the area of $\mathrm{RTH} 40 \%$ is $1.790,3 \mathrm{~m}^{2}$ so that obtained area of station land $4.475,8 \mathrm{~m}^{2}$. In the applicable regulations about station building only discuss KDB or wide awake not RTH needs. So it can be proposed the new calculation to design the environmentally friendly station that discusses area of KDB and RTH so obtained the total land area.
\end{abstract}

Keywords: green infrastrucutre, station, building area, human movements space, Coefficient of Building Base (KDB), Green Open Spaces (RTH). 


\section{PENDAHULUAN}

Kerusakan lingkungan, pemanasan global dan perubahan iklim merupakan beberapa masalah yang terjadi saat ini yang menyebabkan penurunan kualitas bumi. Salah satu yang dianggap memiliki peran besar terhadap perubahan lingkungan tersebut adalah pembangunan proyek infrastruktur, maka pembangunan proyek infrastruktur perlu memperhatikan kondisi lingkungan dengan kata lain membangun proyek infrastruktur yang tidak merusak lingkungan dan memberikan kenyamanan bagi pengguna maupun masyarakat sekitar. Dalam menciptakan suatu bangunan hijau bukan hanya memperhatikan kondisi lingkungan saja melainkan harus memperhatikan juga kondisi pengguna yang ada di dalam area tersebut tentunya dengan kebutuhan ruang gerak yang mencukupi sehingga dapat memberikan kenyamanan bagi pengguna maupun masyarakat sekitar. Mengingat banyaknya infrastruktur yang ada, salah satu infrastruktur yang mendukung moda transportasi kereta api adalah prasarana bangunan stasiun. Untuk mewujudkan kondisi stasiun yang ramah lingkungan dan memberikan kenyamanan bagi pengguna maka dilakukan analisis mengenai luas kebutuhan lahan menurut peraturan yang berlaku sesuai dengan salah satu kriteria bangunan hijau yaitu harus memenuhi Koefisien Dasar Bangunan (KDB) dan kebutuhan Ruang Terbuka Hijau (RTH). Analisis hanya untuk stasiun yang melayani penumpang dengan berdasarkan sumber studi terdahulu dan peraturan yang berlaku serta dengan standar stasiun kereta api menggunakan peraturan yang berlaku sehingga diperoleh usulan atau bahan evaluasi untuk peraturan yang berlaku tersebut dengan mengusulkan perhitungan baru mengenai luas lahan stasiun.

\section{TINJAUAN PUSTAKA}

\subsection{Stasiun}

Stasiun kereta api merupakan prasarana kereta api sebagai tempat pemberangkatan dan pemberhentian kereta api. Menurut Undang-undang Republik Indonesia Nomor 23 (2007) disebutkan bahwa stasiun terdiri dari dua jenis yaitu stasiun kereta api untuk keperluan naik turun penumpang dan stasiun kereta api untuk keperluan bongkar muat barang. Persyaratan penempatan pembangunan stasiun kereta api lokasinya sesuai dengan pola operasi perjalanan kereta api, menunjang operasi sistem perkeretaapian, tidak mengganggu lingkungan, memiliki tingkat keselamatan dan keamanan (Peraturan Menteri Perhubungan Nomor: PM 29, 2011).

\subsection{Persyaratan Pembangunan Peron}

Lebar peron dihitung berdasarkan jumlah penumpang dengan menggunakan Persamaan 1.

$$
b=\frac{\frac{0,64 \mathrm{~m}^{2}}{\text { orang }} * V * L F}{l}
$$

dengan:

$b \quad=$ lebar peron $(\mathrm{m})$,

$V \quad=$ jumlah rata-rata penumpang per jam sibuk dalam satu tahun (orang),

$L F \quad=$ load factor,

$l \quad=$ panjang peron sesuai dengan rangkaian terpanjang kereta api penumpang yang beroperasi $(m)$. 


\subsection{Persyaratan Bangunan}

Menurut Peraturan Menteri Perhubungan Nomor: PM 29 (2011) tentang persyaratan bangunan stasiun, persyaratan operasi bangunan stasiun kereta api adalah sebagai berikut:

1. Konstruksi, material, desain, ukuran dan kapasitas bangunan sesuai dengan standar kelayakan, keselamatan dan keamanan serta kelancaran sehingga seluruh bangunan stasiun dapat berfungsi secara handal.

2. Memenuhi persyaratan keselamatan dan keamanan gedung dari bahaya banjir, bahaya petir, bahaya petir, bahaya kelistrikan dan bahaya kekuatan konstruksi.

3. Instalasi pendukung gedung sesuai dengan peraturan perundang-perundangan tentang bangunan, mekanikal elektrik, dan pemipaan gedung (plumbing) bangunan yang berlaku.

4. Luas bangunan ditetapkan untuk kegiatan pokok dapat dihitung menggunakan

Persamaan 2.

$$
L=0,64 \frac{\mathrm{m}^{2}}{\text { orang }} * V * L F
$$

dengan:

$L \quad=$ luas bangunan $\left(\mathrm{m}^{2}\right)$,

$V \quad=$ jumlah rata-rata penumpang per jam sibuk dalam satu tahun (orang),

$L F \quad=$ load factor.

Sedangkan luas bangunan untuk kegiatan penunjang dan gedung jasa pelayanan khusus di stasiun kereta api, ditetapkan berdasarkan kebutuhan.

5. Menjamin bangunan stasiun dapat berfungsi secara optimal dari segi tata letak ruang gedung stasiun sehingga pengoperasian sarana perkeretaapian dapat dilakukan secara nyaman

\subsection{Standar Perhitungan Luas Ruangan Stasiun Menurut Japan International Cooperation Agency (JICA)}

Kebutuhan ruang yang digunakan dalam perancangan stasiun ini dihitung berdasarkan rumus kebutuhan ruang berdasarkan standar JICA (Baskara, E., 2008) luas standar kebutuhan ruang tersebut ditunjukkan oleh Tabel 1.

Tabel 1. Luas Standar Kebutuhan Ruang

\begin{tabular}{|c|c|c|c|}
\hline No & Ruang & Persamaan & Keterangan Notasi \\
\hline 1 & Hall & $S=A * B$ & $\begin{array}{l}S=\text { luas area hall }\left(\mathrm{m}^{2}\right) \\
A=\text { satuan luas area tunggu penumpang ( } \mathrm{m}^{2} / \text { orang) } \\
B=\text { jumlah penumpang yang menunggu (orang) } \\
c \quad=\text { jumlah penumpang jam sibuk (orang) } \\
q \quad=\% \text { penumpang menunggu pada jam sibuk }\end{array}$ \\
\hline 2 & Kantor Kepala Stasiun & $S=N+14$ & $\begin{array}{ll}S & =\text { luas kantor }\left(\mathrm{m}^{2}\right) \\
N & =\text { jumlah pengunjung kantor (orang) }\end{array}$ \\
\hline 3 & Kantor Stasiun & $S=S_{1}+S_{2}+S_{3}$ & $\begin{array}{l}S=\text { luas standar kantor stasiun }\left(\mathrm{m}^{2}\right) \\
S_{1}=\text { luas meja kepala }\left(\mathrm{m}^{2}\right) \\
S_{2}=\text { luas meja } \operatorname{staff}\left(\mathrm{m}^{2}\right) \\
S_{3}=\text { luas ruang untuk staff tanpa meja }\left(\mathrm{m}^{2}\right)\end{array}$ \\
\hline 4 & Ruang Rapat & $S=a * N$ & $\begin{array}{ll}S & =\text { luas standar luas ruang rapat }\left(\mathrm{m}^{2}\right) \\
a & =\text { luas standar pengunjung (m²/orang) } \\
N & =\text { jumlah orang yang ikut rapat (orang) }\end{array}$ \\
\hline 5 & Loket Karcis & $n=\frac{t}{b}$ & $\begin{array}{ll}n & =\text { jumlah mesin (buah) } \\
t & =\text { jumlah penumpang pembeli tiket (orang) } \\
b & =\text { kapasitas pemesanan }\end{array}$ \\
\hline
\end{tabular}


Tabel 1. Luas Standar Kebutuhan Ruang (lanjutan)

\begin{tabular}{|c|c|c|c|}
\hline No & Ruang & Persamaan & Keterangan Notasi \\
\hline 6 & Ruang Antri Tiket & $S_{1}=L_{1}+L_{2}$ & $\begin{array}{l}S_{1}=\text { luas area hall mesin tiket }\left(\mathrm{m}^{2}\right) \\
L_{1}=\text { lebar loket } * \text { jumlah loket }(\mathrm{m}) \\
L_{2}=\text { panjang antrian }(\mathrm{m})\end{array}$ \\
\hline 7 & Ruang Tunggu & $S=a * n$ & $\begin{array}{l}S=\text { luas standar ruang rapat }\left(\mathrm{m}^{2}\right) \\
a=\text { jumlah karyawan (orang) } \\
n=\text { luas per orang ( } \mathrm{m}^{2} / \text { orang) }\end{array}$ \\
\hline
\end{tabular}

\subsection{Kebutuhan Ruang Pejalan Kaki Berdasarkan Dimensi Tubuh Manusia}

Menurut Peraturan Menteri Pekerjaan Umum Nomor: 03/PRT/M (2014) tentang Pedoman Perencanaan, Penyediaan dan Pemanfaatan Prasarana dan Sarana Jaringan Pejalan Kaki Di Kawasan Perkotaan menyatakan bahwa kebutuhan ruang minimum pejalan kaki antara lain:

1. Tanpa membawa barang dan keadaan diam yaitu $0,27 \mathrm{~m}^{2}$,

2. Tanpa membawa barang dan keadaan bergerak yaitu $1,08 \mathrm{~m}^{2}$,

3. Membawa barang dan keadaan bergerak yaitu antara $1,35 \mathrm{~m}^{2}$ sampai dengan $1,6 \mathrm{~m}^{2}$. Kebutuhan ruang minimum untuk berdiri, bergerak dan membawa barang dapat dilihat pada Gambar 1 kebutuhan ruang gerak minimum di bawah ini harus memperhatikan kondisi perilaku pejalan kaki dalam melakukan pergerakan baik pada saat membawa barang, maupun berjalan bersama dengan pelaku pejalan kaki lainnya.

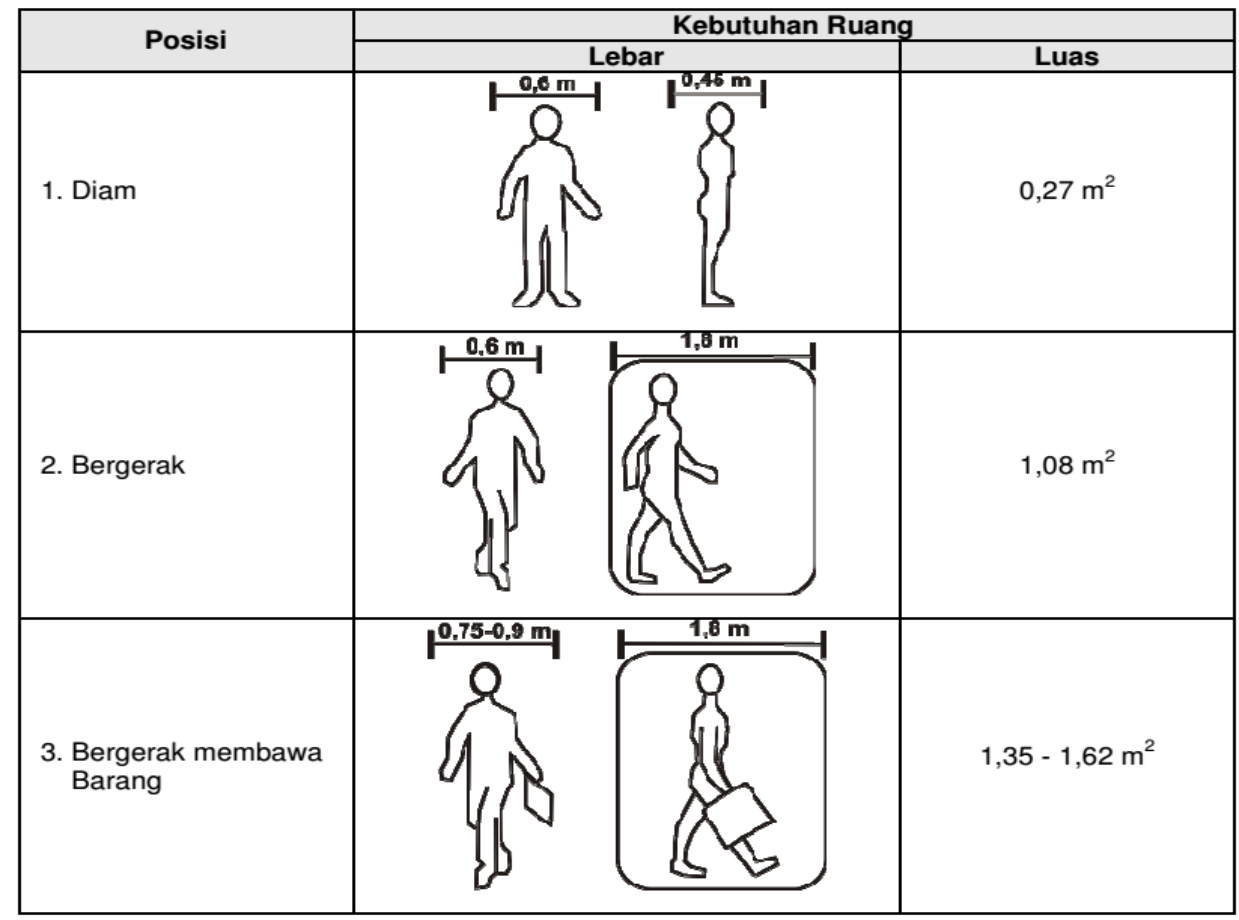

Gambar 1. Kebutuhan ruang gerak minimum pejalan kaki (Sumber: Peraturan Menteri Pekerjaan Umum Nomor: 03/PRT/M/2014)

\subsection{Ruang Jalur Pejalan Kaki Berkebutuhan Khusus}

Menurut Peraturan Menteri Pekerjaan Umum Nomor: 03/PRT/M (2014) tentang Pedoman Perencanaan, Penyediaan dan Pemanfaatan Prasarana dan Sarana Jaringan Pejalan Kaki Di Kawasan Perkotaan menyatakan bahwa persyaratan khusus ruang bagi pejalan kaki yang mempunyai keterbatasan fisik (difabel) antara lain:

1. Jalur pejalan kaki memiliki lebar minimum 1,5 meter dan luas minimum $2,25 \mathrm{~m}^{2}$, 
2. Alinyemen jalan dan kelandaian jalan mudah dikenali oleh pejalan kaki antara lain melalui penggunaan material khusus,

3. Menghindari berbagai bahaya yang berpotensi mengancam keselamatan seperti jeruji dan lubang,

4. Tingkat trotoar harus dapat memudahkan dalam menyebrang jalan,

5. Dilengkapi jalur pemandu dan perangkat untuk menunjukkan berbagai perubahan dalam tekstur trotoar,

6. Permukaan jalan tidak licin,

7. Jalur pejalan kaki dengan ketentuan kelandaian yaitu sebagai berikut:

a. Tingkat kelandaian tidak melebihi dari $8 \%(1: 12)$,

b. Jalur yang landai harus memiliki pegangan tangan setidaknya untuk satu sisi atau disarankan kedua sisi. Pada akhir landai setidaknya panjang pegangan tangan mempunyai kelebihan sekitar 0,3 meter,

c. Pegangan tangan harus dibuat dengan ketinggian 0,8 meter diukur dari permukaan tanah dan panjangnya harus melebihi anak tangga terakhir,

d. Seluruh pegangan tangan tidak diwajibkan memiliki permukaan yang licin,

e. Area landai harus memiliki penerangan yang cukup.

Ketentuan untuk fasilitas bagi pejalan kaki berkebutuhan khusus adalah sebagai berikut:

1. Ramp diletakan disetiap persimpangan, prasarana ruang pejalan kaki yang memasuki pintu keluar masuk bangunan atau kaveling dan titik-titik penyebrangan,

2. Jalur difabel diletakkan sepanjang prasarana jaringan pejalan kaki,

3. Pemandu atau tanda-tanda bagi pejalan kaki antara lain meliputi: tanda-tanda pejalan kaki yang dapat diakses, sinyal suara yang dapat didengar, pesan-pesan verbal, informasi lewat getaran dan tekstur ubin sebagai pengarah dan peringatan.

Ketentuan mengenai standar penyediaan jalur pejalan kaki berkebutuhan khusus secara lebih rinci mengacu pada pedoman mengenai teknis fasilitas dan aksesibilitas pada bangunan gedung dan lingkungan.

\subsection{Koefisien Dasar Bangunan (KDB)}

Menurut Peraturan Daerah Provinsi Daerah Khusus Ibukota Jakarta Nomor 1 (2014) menyatakan bahwa Koefisien Dasar Bangunan (KDB) adalah angka persentase perbandingan antara luas seluruh lantai dasar bangunan dan luas lahan perpetakan atau lahan perencanaan yang dikuasai sesuai Rencana Tata Ruang Wilayah, Rencana Detail Tata Ruang dan Peraturan Zonasi. Zona yang digunakan adalah zona perkantoran, perdagangan dan jasa yang merupakan zona yang diperuntukan bagi kegiatan perkantoran, perdagangan dan jasa untuk mendukung efisiensi perjalanan, memiliki akses yang tinggi berupa jalur pejalan kaki yang terhubung dengan jaringan transportasi massal dan jalur penghubung antar bangunan dan didukung dengan fasilitas umum dan pasokan energi dengan teknologi yang memadai. Besar nilai persentase yang digunakan maksimum $60 \%$ dari luas lahan keseluruhan (Peraturan Daerah Provinsi Daerah Khusus Ibukota Jakarta Nomor 1, 2014).

\subsection{Koefisien Lantai Bangunan (KLB)}

Menurut Peraturan Daerah Provinsi Daerah Khusus Ibukota Jakarta Nomor 1 (2014) menyatakan bahwa Koefisien Lantai Bangunan (KLB) adalah angka persentase perbandingan antara luas seluruh lantai bangunan gedung dan luas lahan perpetakan atau lahan perencanaan yang dikuasai sesuai Rencana Tata Ruang Wilayah, Rencana Detail Tata Ruang dan Peraturan Zonasi. Zona yang digunakan adalah zona perkantoran, perdagangan dan jasa yang merupakan zona yang diperuntukan bagi kegiatan perkantoran, perdagangan dan jasa untuk mendukung efisiensi perjalanan, memiliki akses yang tinggi berupa jalur pejalan kaki yang terhubung dengan jaringan transportasi massal dan jalur penghubung antar bangunan dan didukung dengan fasilitas umum dan pasokan energi dengan teknologi yang 
memadai. Besar nilai KLB yang digunakan adalah sebesar 2,4 (dua koma empat) dari KDB dan ketinggian bangunan paling tinggi 4 (empat) lantai (Peraturan Daerah Provinsi Daerah Khusus Ibukota Jakarta Nomor 1, 2014).

\subsection{Ruang Terbuka Hijau (RTH)}

Menurut Peraturan Daerah Provinsi Daerah Khusus Ibukota Jakarta Nomor 1 (2014) menyatakan bahwa Ruang Terbuka Hijau (RTH) adalah ruang-ruang dalam kota dalam bentuk area atau kawasan maupun memanjang atau jalur yang didominasi oleh tumbuhan yang dibina untuk fungsi perlindungan habitat tertentu dan/atau sarana kota, dan/atau pengaman jaringan prasarana dan/atau budidaya pertanian. Besar ruang terbuka hijau adalah sebesar $40 \%$ dari luas lahan keseluruhan.

\section{METODE PENELITIAN}

\subsection{Identifikasi Masalah dan Tujuan Penelitian}

Dalam menciptakan suatu stasiun yang ramah lingkungan bukan hanya memperhatikan kondisi lingkungan saja melainkan harus memperhatikan konsisi pengguna di dalam area stasiun tersebut dengan kebutuhan ruang gerak yang mencukupi sehingga dapat memberikan kenyamanan bagi pengguna. Untuk mewujudkan kondisi stasiun yang ramah lingkungan dan memberikan kenyamanan bagi pengguna harus menciptakan suatu kebutuhan ruang gerak dan luasan stasiun yang sesuai dengan jumlah pengguna di stasiun sehingga perlu ada suatu kriteria yang dapat dijadikan acuan dalam pembangunan bangunan stasiun tersebut dan memperoleh persentase luas ruang fasilitas di stasiun khususnya stasiun penumpang serta kebutuhan luas rencana yang dihitung berdasarkan Koefisien Dasar Bangungan (KDB), Koefisien Luas Bangunan (KLB), Koefisien Dasar Hijau $(\mathrm{KDH})$ yang berlaku di Indonesia.

\subsection{Tinjauan Pustaka}

Sebelum penelitian dimulai terlebih dahulu akan dilakukan tinjauan pustaka. Tinjauan pustaka berisi tentang pemikiran atau teori-teori yang dapat dijadikan sebagai landasan atau studi literatur dalam menyusun konsep penelitian ini. Studi literatur yang digunakan berkaitan dengan perhitungan ruang gerak di stasiun yang bersumber dari studi terdahulu dan Peraturan Menteri Pekerjaan Umum Nomor: 03/PRT/M/2014 serta perhitungan standar luas bangunan stasiun kereta api yang bersumber dari Peraturan Menteri Perhubungan Nomor: PM 29 tahun 2011, Peraturan Menteri Perhubungan Nomor: PM 48 tahun 2015 dan Japan International Cooperation Agency (JICA).

\subsection{Pengumpulan Data Sekunder Berdasarkan Ruang Gerak Manusia}

Diperlukan beberapa data pendukung mengenai ruang gerak manusia untuk dapat menyelesaikan penelitian ini. Data tersebut bersumber dari studi terdahulu dan Peraturan Menteri Pekerjaan Umum Nomor: 03/PRT/M/2014 tentang Pedoman Perencanaan, Penyediaan dan Pemanfaatan Prasarana dan Sarana Jaringan Pejalan Kaki Di Kawasan Perkotaan

\subsection{Pengumpulan Data Sekunder Berdasarkan Standar Stasiun Kereta Api}

Diperlukan beberapa data pendukung mengenai standar luas bangunan stasiun kereta api untuk dapat menyelesaikan penelitian ini. Data tersebut bersumber dari Peraturan Menteri Perhubungan Nomor: PM 29 tahun 2011 tentang Persyaratan Teknis Bangunan Stasiun Kereta Api, Peraturan Menteri Perhubungan Nomor: PM 48 tahun 2015 tentang Standar Pelayanan Minimum Angkutan Orang Dengan Kereta Api dan Japan International Cooperation Agency (JICA). 


\subsection{Pengolahan Data}

Pada tahap ini peneliti akan mengolah literatur-literatur yang telah dikumpulkan. Pengolahan data yang dilakukan adalah mengevaluasi parameter kebutuhan perhitungan luas stasiun dengan membandingkan luas stasiun tersebut dengan ruang gerak manusia. Kemudian dipilih kriteria perencanaan stasiun berdasarkan Peraturan Menteri Perhubungan Nomor: PM 29 tahun 2011, antara lain:

1. Gedung untuk kegiatan pokok

Macam-macam gedung untuk kegiatan pokok antara lain:

a. hall,

b. perkantoran kegiatan stasiun,

c. loket karcis,

d. ruang tunggu,

e. ruang informasi,

f. ruang fasilitas umum,

g. ruang fasilitas keselamatan,

h. ruang fasilitas keamanan,

i. ruang fasilitas penyandang cacat dan lansia,

j. ruang fasilitas kesehatan.

2. Gedung untuk kegiatan penunjang

Macam-macam gedung untuk kegiatan penunjang di stasiun kereta api, antara lain:

a. pertokoan,

b. restoran,

c. perkantoran,

d. tempat parkir,

e. perhotelan,

f. ruang lain yang menunjang langsung kegiatan stasiun kereta api.

3. Gedung untuk kegiatan jasa pelayanan khusus

Macam-macam gedung untuk kegiatan jasa pelayanan khusus di stasiun kereta api antara lain:

a. ruang tunggu penumpang,

b. bongkar muat barang,

c. pergudangan,

d. parkir kendaraan,

e. penitipan barang,

f. ruang atm,

g. ruang lain yang menunjang baik secara langsung maupun tidak langsung di dalam kawasan kegiatan stasiun kereta api.

Dari kriteria tersebut hanya digunakan fasilitas yang hanya untuk pelayanan penumpang dan semua kriteria disesuaikan dengan nilai kebutuhan manusia berdasarkan Peraturan Menteri Perhubungan Nomor: PM 29 tahun 2011 akan disesuaikan dengan nilai kebutuhan manusia untuk membangun sebuah bangunan hijau.

\subsection{Analisis Kebutuhan Luas Bangunan dan Luas Lahan Stasiun Kereta Api}

Sesuai dengan tujuan penelitian mengenai kebutuhan luas lahan untuk stasiun kereta api, maka dilakukan analisis kebutuhan luas lahan stasiun kereta api menurut Peraturan Menteri Perhubungan Nomor: PM 29 tahun 2011 dengan memperhitungkan luas kebutuhan lahan yang sesuai dengan kriteria bangunan hijau, yaitu memenuhi koefisien dasar bangunan dan kebutuhan ruang terbuka hijau. Komponen stasiun kereta api yang tertuang dalam peraturan menteri perhubungan, selanjutnya dikembangkan dengan cara mencari formula yang tepat untuk menghitung kebutuhan lahan setiap komponen stasiun. Berdasarkan studi terdahulu 
yang terkait dengan bangunan hijau, maka dapat diusulkan beberapa formula baru perhitungan komponen luas stasiun.

\subsection{Simpulan dan Saran}

Memberikan usulan atau mengevaluasi Peraturan Menteri Perhubungan Nomor: PM 29 tahun 2011 bahwa rumus yang terdapat di peraturan hanya menghitung luas terbangun atau Koefisien Dasar Bangunan (KDB) dengan kata lain belum termasuk dengan luas tanah yang ada. Oleh karena itu untuk menghitung luas tanah, harus menambahkan lahan untuk Ruang Terbuka Hijau (RTH). Serta memberikan beberapa saran untuk penelitian selanjutnya.

\section{PENGOLAHAN DATA DAN ANALISIS}

Dari hasil perhitungan didapatkan rekapitulasi luas stasiun atau KDB sebesar $60 \%$ dapat dilihat pada Tabel $\mathbf{2}$ dan grafik persentase luas stasiun dapat dilihat pada Gambar 2. Kemudian didapatkan hasil luas stasiun berdasarkan sumber-sumber yang digunakan dan berdasarkan peraturan yang berlaku, dapat dilihat pada Tabel $\mathbf{3}$ serta rekapitulasi rumus yang digunakan dapat dilihat pada Tabel 4.

Tabel 2. Rekapitulasi Luas Bangunan

\begin{tabular}{|c|c|c|c|}
\hline No & Ruang & Luas $\left(\mathbf{m}^{2}\right)$ & $(\%)$ \\
\hline 1 & Hall & 432 & 16,09 \\
\hline 2 & Perkantoran & 72 & 2,68 \\
\hline 3 & Loket Karcis & 22,5 & 0,84 \\
\hline 4 & Ruang Tunggu & 24 & 0,89 \\
\hline 5 & Ruang Informasi & 22,5 & 0,84 \\
\hline 6 & Ruang Fasilitas Umum & 327,68 & 12,20 \\
\hline 7 & Ruang Fasilitas Kesehatan & 4,32 & 0,16 \\
\hline 8 & Ruang Fasilitas Keamanan & 25 & 0,93 \\
\hline 9 & Pertokoan & 100 & 3,72 \\
\hline 10 & Restoran & 140 & 5,21 \\
\hline 11 & Parkir Kendaraan & 672,5 & 25,04 \\
\hline 12 & Ruang ATM & 27 & 1,01 \\
\hline 13 & Peron & 816 & 30,39 \\
\hline & Total & 2685,5 & 100 \\
\hline
\end{tabular}

Tabel 3. Rekapitulasi Seluruh Luas Ruang Fasilitas di Stasiun

\begin{tabular}{ccccccc} 
No & Ruang & $\begin{array}{c}\text { PM No } \\
\mathbf{2 9 ,} \mathbf{2 0 1 1} \\
\left(\mathbf{m}^{\mathbf{2}}\right)\end{array}$ & $\begin{array}{c}\text { JICA } \\
\left(\mathbf{m}^{\mathbf{2}}\right)\end{array}$ & $\begin{array}{c}\text { Ruang Gerak } \\
\text { Manusia } \\
\left(\mathbf{m}^{2}\right)\end{array}$ & $\begin{array}{c}\text { Studi } \\
\text { Terdahulu } \\
\left(\mathbf{m}^{\mathbf{2}}\right) *\end{array}$ & $\begin{array}{c}\text { PM No 48, } \\
\mathbf{2 0 1 5} \\
\left(\mathbf{m}^{\mathbf{2}}\right)\end{array}$ \\
\hline 1 & Hall & 163,9 & 224 & 432 & - & - \\
\hline 2 & Perkantoran & 8,2 & 67,5 & 72 & - & - \\
\hline 3 & Loket Karcis & 3 & 5,65 & 22,5 & - & 24 \\
\hline 4 & Ruang Tunggu & 20,5 & & & - & - \\
\hline 5 & Ruang Informasi & 2,56 & 20 & 22,5 & & - \\
\hline
\end{tabular}


Tabel 3. Rekapitulasi Seluruh Luas Ruang Fasilitas di Stasiun (lanjutan)

\begin{tabular}{|c|c|c|c|c|c|c|}
\hline No & Ruang & $\begin{array}{c}\text { PM No } \\
29,2011 \\
\left(\mathrm{~m}^{2}\right)\end{array}$ & $\begin{array}{l}\text { JICA } \\
\left(\mathrm{m}^{2}\right)\end{array}$ & $\begin{array}{c}\text { Ruang Gerak } \\
\text { Manusia } \\
\left(\mathbf{m}^{2}\right)\end{array}$ & $\begin{array}{c}\text { Studi } \\
\text { Terdahulu } \\
\left(\mathrm{m}^{2}\right) *\end{array}$ & $\begin{array}{c}\text { PM No 48, } \\
2015 \\
\left(\mathrm{~m}^{2}\right)\end{array}$ \\
\hline 6 & $\begin{array}{c}\text { Ruang Fasilitas } \\
\text { Umum }\end{array}$ & 327,68 & - & - & 120 & - \\
\hline 7 & $\begin{array}{c}\text { Ruang Fasilitas } \\
\text { Keamanan }\end{array}$ & - & - & 4,32 & - & - \\
\hline 8 & $\begin{array}{c}\text { Ruang Fasilitas } \\
\text { Kesehatan }\end{array}$ & - & - & - & 25 & - \\
\hline 9 & Pertokoan & - & - & 86,4 & 100 & - \\
\hline 10 & Restoran & - & - & - & 140 & - \\
\hline 11 & Parkir Kendaraan & - & - & - & 672,5 & - \\
\hline 12 & Ruang ATM & - & - & 27 & - & - \\
\hline 13 & Peron & 816 & - & - & - & - \\
\hline
\end{tabular}

*=(Sumber: Adenan, K., 2008)

Berdasarkan tabel di atas diambil luasan yang paling besar. Jika kebutuhan Peraturan Menteri Perhubungan Nomor: PM 29 tahun 2011 tidak mengakomodir perhitungan tersebut maka diasumsikan menggunakan ketentuan lainnya seperti Japan International Cooperation Agency (JICA), rumus ruang gerak manusia menurut Peraturan Menteri Pekerjaan Umum Nomor: 03/PRT/M/2014 dan studi terdahulu Adapun memaparkan kriteria menurut Peraturan Menteri Perhubungan Nomor: PM 48 tahun 2015.

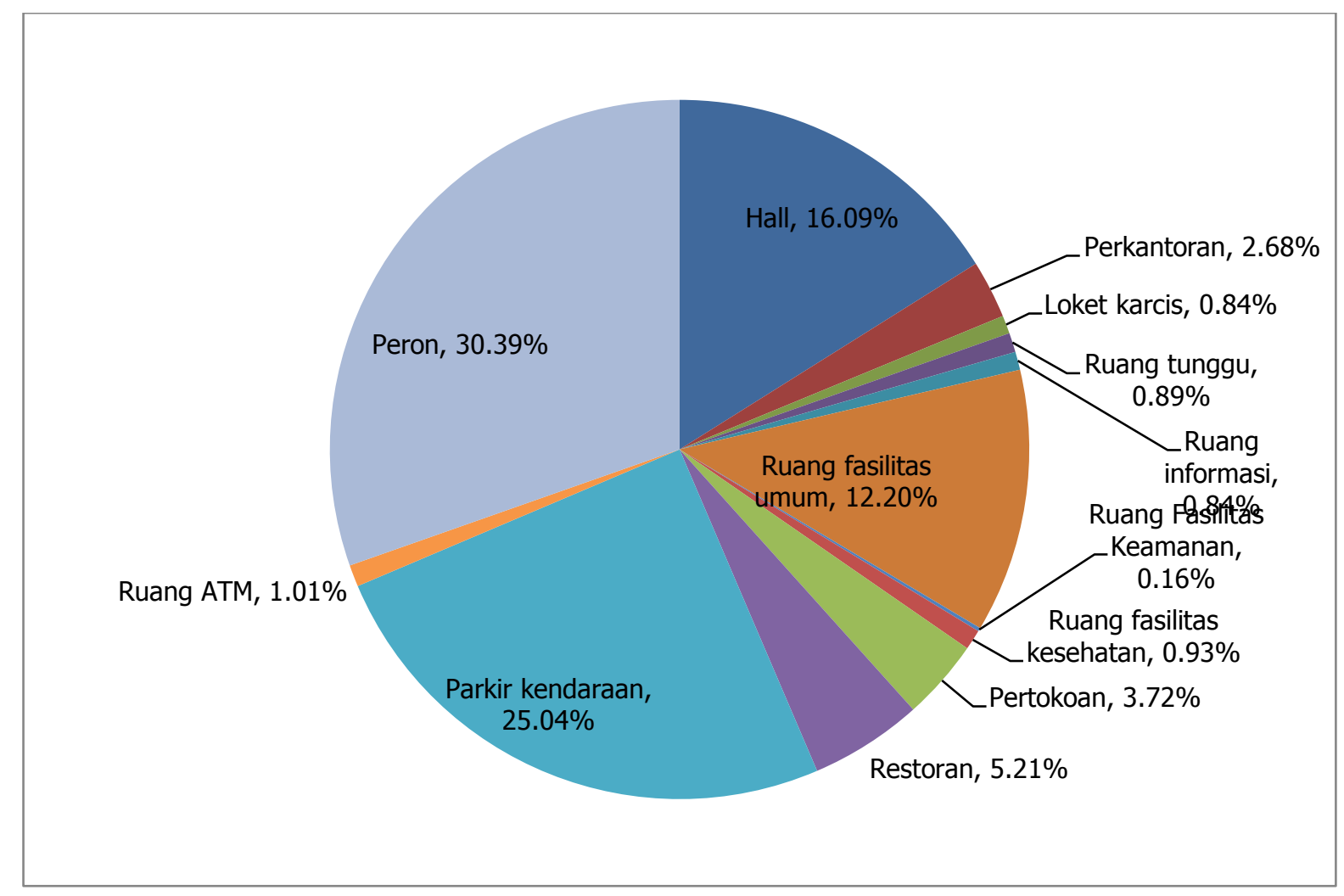

Gambar 2. Grafik persentase luas stasiun berdasarkan hasil analisis 
Tabel 4. Rekapitulasi Rumus yang Digunakan

\begin{tabular}{|c|c|c|c|}
\hline No & Ruang & Sumber & Rumus \\
\hline 1 & Hall & $\begin{array}{c}\text { Ruang gerak manusia berdasarkan } \\
\text { Peraturan Menteri Pekerjaan Umum } \\
\text { Nomor: 03/PRT/M/2014 }\end{array}$ & $\begin{aligned} L= & 1,35 * \text { jumlah orang } \\
& \text { yang ada di hall }\end{aligned}$ \\
\hline 2 & Perkantoran & $\begin{array}{c}\text { Ruang gerak manusia berdasarkan } \\
\text { studi terdahulu }\end{array}$ & $\begin{array}{c}L=4,5 \text { sampai dengan } 25 \\
* \text { jumlah orang yang bekerja }\end{array}$ \\
\hline 3 & Loket Karcis & $\begin{array}{c}\text { Ruang gerak manusia berdasarkan } \\
\text { studi terdahulu }\end{array}$ & $\begin{array}{c}L=4,5 \text { sampai dengan } 25 \\
* \text { jumlah orang yang bekerja }\end{array}$ \\
\hline 4 & Ruang Tunggu & $\begin{array}{l}\text { Ruang gerak manusia berdasarkan } \\
\text { Peraturan Menteri Perhubungan } \\
\text { Nomor: PM } 48 \text { tahun } 2015\end{array}$ & $\begin{array}{c}L=2,5 \% \\
* \text { jumlah orang yang ada } \\
\text { di ruang tunggu } * 0,6\end{array}$ \\
\hline 5 & Ruang Informasi & $\begin{array}{l}\text { Ruang gerak manusia berdasarkan } \\
\text { studi terdahulu }\end{array}$ & $\begin{array}{c}L=4,5 \text { sampai dengan } 25 \\
* \text { jumlah orang yang bekerja }\end{array}$ \\
\hline 6 & $\begin{array}{l}\text { Ruang Fasilitas } \\
\text { Umum }\end{array}$ & $\begin{array}{c}\text { Peraturan Menteri Perhubungan } \\
\text { Nomor: PM } 29 \text { tahun } 2011\end{array}$ & $\begin{array}{c}L=0,64 * \text { jumlah orang } \\
\text { yang menggunakan fasilitas umum } * \mathrm{LF}\end{array}$ \\
\hline 7 & $\begin{array}{c}\text { Ruang Fasilitas } \\
\text { Keamanan }\end{array}$ & $\begin{array}{c}\text { Peraturan Menteri Pekerjaan Umum } \\
\text { Nomor: 03/PRT/M/2014 }\end{array}$ & $L=0,27 *$ jumlah petugas keamanan \\
\hline 8 & $\begin{array}{c}\text { Ruang Fasilitas } \\
\text { Kesehatan }\end{array}$ & $\begin{array}{c}\text { Ruang gerak manusia berdasarkan } \\
\text { studi terdahulu }\end{array}$ & $L=$ kapasitas orang $* 5$ \\
\hline 9 & Pertokoan & $\begin{array}{c}\text { Ruang gerak manusia berdasarkan } \\
\text { Peraturan Menteri Pekerjaan Umum } \\
\text { Nomor: 03/PRT/M/2014 }\end{array}$ & $L=$ jumlah toko $* 10$ \\
\hline 10 & Restoran & $\begin{array}{l}\text { Ruang gerak manusia berdasarkan } \\
\text { studi terdahulu }\end{array}$ & $\begin{array}{c}L=\text { jumlah restoran } \\
* \text { kapasitas orang } * 1,4\end{array}$ \\
\hline 11 & Parkir Kendaraan & $\begin{array}{l}\text { Ruang gerak manusia berdasarkan } \\
\text { studi terdahulu }\end{array}$ & $\begin{array}{c}L=2,5 * \text { jumlah penumpang } \\
\text { yang membawa kendaraan bermotor } \\
L=75 * \text { jumlah penumpang } \\
\text { yang membawa kendaraan bermotor }\end{array}$ \\
\hline 12 & Ruang ATM & $\begin{array}{c}\text { Ruang gerak manusia berdasarkan } \\
\text { studi terdahulu }\end{array}$ & $\begin{array}{c}L=1,5 * \text { jumlah mesin ATM } \\
* \text { panang antrian }\end{array}$ \\
\hline 13 & Peron & $\begin{array}{l}\text { Ruang gerak manusia berdasarkan } \\
\text { studi terdahulu }\end{array}$ & $L=0,64 *$ jumlah penumpang $* \mathrm{LF}$ \\
\hline
\end{tabular}

Dari tabel di atas dapat disimpulkan bahwa luas stasiun yang terbesar adalah berdasarkan ruang gerak manusia. Luas total adalah penjumlahan dari hasil rumus yakni $60 \%$ dari KDB atau luas terbangun, untuk luas lahan total ditambah dengan $40 \%$ RTH sehingga rumus untuk luas lahan total seperti Persamaan 3.

$$
L_{\text {lahan stasiun }}=L_{\text {stasiun }}+R T H
$$

Dari rumus tersebut disimpulkan bahwa luas lahan stasiun harus memenuhi koefisien dasar bangunan sebesar $60 \%$ ditambah luas ruang terbuka hijau sebesar $40 \%$.

\section{KESIMPULAN}

Berdasarkan hasil penelitian dan pembahasan dapat disimpulkan sebagai berikut:

1. Berdasarkan hasil analisis perhitungan didapatkan luas stasiun atau luas terbangun yakni KDB $60 \%$ adalah sebesar $2.685,5 \mathrm{~m}^{2}$ dan luas untuk RTH $40 \%$ adalah sebesar $1.790,3 \mathrm{~m}^{2}$ jadi didapatkan luas lahan stasiun $100 \%$ adalah sebesar $4.475,8 \mathrm{~m}^{2}$. Perhitungan ini hanya berdasarkan simulasi dengan studi kasus jumlah penumpang sebesar 1600 orang/jam. 
2. Bahwa dalam Peraturan Menteri Perhubungan Nomor: PM 29 tahun 2011 hanya menghitung luas bangunan atau luas terbangun yang mana luas terbangun tersebut adalah $60 \%$ dari luas kebutuhan lahan.

3. Perencanaan kebutuhan luas lahan mengikuti kebutuhan Ruang Terbuka Hijau (RTH) dimana RTH tersebut diambil dari Peraturan Menteri Pekerjaan Umum Nomor: 03/PRT/M/2014 sebesar $40 \%$.

4. Kebutuhan luas lahan stasiun dihitung berdasarkan rumus yang sudah diadaptasi dari aturan yang lain. Dalam analisis yang telah dilakukan maka diusulkan perubahan untuk perhitungan luas fasilitas yang ada di stasiun.

5. Berdasarkan hasil analisis perhitungan kebutuhan luas stasiun yang ramah lingkungan, selanjutnya dapat diketahui bobot persentase kebutuhan luas untuk setiap komponen/bagian bangunan berdasarkan fungsinya di stasiun kereta api.

\section{DAFTAR RUJUKAN}

Adenan, K. (2008). Stasiun Kereta Api Penumpang Gedebage Bandung. Bandung: Institut Teknologi Bandung.

Baskara, E. (2008). Stasiun Interchange Dukuh Atas. Bandung: Institut Teknologi Bandung.

Menteri Pekerjaan Umum Republik Indonesia. (2014). Peraturan Daerah Provinsi Daerah Khusus Ibukota Jakarta Nomor 1 Tahun 2014 tentang Rencana Detail Tata Ruang dan Peraturan Zonasi. Jakarta: Kementerian Pekerjaan Umum.

Menteri Pekerjaan Umum Republik Indonesia. (2014). Peraturan Menteri Pekerjaan Umum Nomor : 03/PRT/M/2014 tentang Pedoman Perencanaan Penyediaan dan Sarana Jaringan Pejalan Kaki. Jakarta: Kementerian Pekerjaan Umum.

Menteri Perhubungan Republik Indonesia. (2011). Peraturan Menteri Perhubungan Nomor : PM. 29 Tahun 2011 tentang Persyaratan Teknis Bangunan Stasiun Kereta Api. Jakarta: Kementerian Perhubungan. 